\title{
Mahmoud Darwish and Joy Harjo: Cosmic Consciousness
}

\author{
Adil M. Jamil \\ Department of English, Faculty of Arts and Sciences \\ Amman Arab University. Amman, Jordan
}

\begin{abstract}
:
This study examines the phases of human consciousness revealed in the poetry of indigenous people in the light of some prominent psychologists and philosophers mainly Bucke, Schleiermacher, William James, Hegel, and Moores. Bucke and Schleiermacher cited three forms of consciousness: Animal or Brutish Self-awareness, Sensual or Self-Consciousness, and Cosmic Consciousness. While examining the poetry of indigenous people, Palestinians and Native Americans, we find out that the majority moves within the confines of the Sensual or SelfConsciousness in their reaction to the brutish consciousness of the oppressors who deny their unalienable rights for life, liberty, and pursuit of happiness. Unlike others, Mahmoud Darwish, the Palestinian, and Joy Harjo, the Native American, attempt to transcend the sensual consciousness and adopt a broader universal vision or cosmic consciousness; however, their peaceful vision is often shattered by bitter realities and frustrated by the inhuman conduct of their oppressors. In their verses, the particular or the sensual is not completely overlooked or concealed. It is always there, yet alleviated by a universal vision held by the two poets
\end{abstract}

Keywords: Animal or Brutish Consciousness, Cosmic consciousness, Darwish, Harjo, Native Americans, Palestinians, Sensual or Self-Consciousness

Cites as: Jamil, A. M. (2019). Mahmoud Darwish and Joy Harjo: Cosmic Consciousness. Arab World English Journal for Translation \& Literary Studies, 3 (3) 20-36.

DOI: http://dx.doi.org/10.24093/awejtls/vol3no3.2 


\section{Introduction}

Before examining the poetry of indigenous people, one may feel inclined yo shed some light upon the phases of human consciousness as noted by Bucke and Schleiermacher. In their studies of the evolution of human mind, they infer that human consciousness develops into three -phases: Brutish Self-awareness, or Simple Consciousness, possessed by both animals and ancient people; Sensual or Self-Consciousness, possessed by common man, encompassing thought, reason, and imagination; and Higher Self-Consciousness, or Cosmic Consciousness, the highest form, or the pinnacle of human consciousness (Bucke, 2009 p.1-30). For certain the highest is the rarest and often seen in the words and action of godlike figures who possess the capability of transcending animal instincts and Sensual Consciousness, attaining a point of contact with God or the absolute, and seeing the cosmos as entirely immaterial, spiritual, and alive. To those rare individuals all the creatures of God become one. Every living creature has eternal life and belongs to the same cosmic web.

\section{Cosmic Consciousness and Song of Myself}

Cosmic Consciousness as a term was first coined by Richard Maurice Bucke, in his book Cosmic Consciousness: A Study in the Evolution of the human Mind, in which he relies heavily on Schleiermacher's earlier manifestations. Bucke explores concept as part of his investigation of the development of man's mystic relation to the infinite as revealed in the most acclaimed poem Song of Myself of Whitman, whom Bucke considers the climax of religious evolution and the harbinger of humanity's future (Robertson, 2010, p.135; Parini,2011). In Song of Myself, Whitman lays grounds for a peculiar vision and offers substantial outline for Bucke's import. In Whitman's verses, the particular entirely retreats giving room for a more universal vision or at best mingled together (Cook, 1950). Whitman sees himself in everyone, and everyone in himself regardless of race, religion, or gender: "For every atom belonging to me as good belongs to you" (Section 1); and "In all people I see myself, none more and not one a barleycorn less/and the good or bad I say of myself I say of them"(Section 20). In (Section 47), he sees himself as an agent of all common men: "It is you talking just as much as myself... I act as the tongue of you". Whitman transcends the confines of sensual consciousness, and becomes a union of opposites, a melting pot, where all universal contraries reside and mingle (Section 52). Furthermore, all the contraries are essential and belong to the same web, and every individual is equal and an expression of the whole. To Whitman, as it is to Hegel's Geist, God is not a being separate from the universe, instead God is part of His own creation and can be seen everywhere and in everything. His presence in men and nature made them divine; and thus humanity is godlike, neither innately wicked nor worth lamenting (Huysteen, 2003). As well, Whitman, like William James, internalizes that all religions have a common core regardless of any various institutional accession and ritual; and that mystical illumination is the foundation of all spiritual experiences. In mystic states, all individuals become one with the Absolute and become aware of universal oneness, as William James often advocates (James 1892). Equally important, Moores believes that the experience of cosmic consciousness is incomplete without the element of love (Moores 2006 pp. 33-34). In addition, the universe is orderly designed, no ultimate death nor chaos in the universe. When dying, man is going to give his body back to nature and continue his immortal journey. By large, Whitman's Cosmic 
Consciousness can be understood as an idealistic vision that transcends customary human concerns, vices, pains, miseries, and sees the cosmos as one regardless of gender, race, or religion. Whitman calls for a mystic unison of the whole world where love, mutual respect and tolerance prevail. Such a vision is hardly seen in the verses of indigenous people with very rare exceptions, however.

\section{Afflictions of Both Palestinians and Native Americans}

Historical records speak bluntly about the resemblance in affliction of both Native Americans and Palestinians. Both nations were exploited and abused. Many were forced to relocate or leave their homeland behind, and sought asylums worldwide. The ones who held up to their ground suffered various forms of persecution, indignation, and segregation. In the $19^{\text {th }}$ Century, Native Americans were forcedly rooted out of their homeland and driven like herds to other designated lands, later called the Reservations. Palestinians have suffered the same fate. After long centuries of peaceful co-existence with other inhabitants, in the $20^{\text {th }}$ Century Palestinians were forced to leave their homeland and to be squeezed into refugee camps in the neighboring countries, especially Jordan, Syria, Lebanon, and Egypt. Ironically, in both regions, unverified religious prophecies are used to legitimize aggression and exploitation of others. The so-called American prophecy of Manifest Destiny and the so-called Israeli prophecy of Promised Land are used excessively to achieve political ends. In reaction to the plight of both nations, poets reveal various forms of consciousness: seldom brutish consciousness, often sensual or self-consciousness, and rarely cosmic consciousness.

\section{Poetry of Palestinians}

In examining the poetry of Palestinians, one may infer that most inclinations fall within the confines of Sensual Consciousness. The particular plight takes the center stage, whereas the universal, or the mystical, is mostly missing. Many popular poems were collected by Kanafani and classified as poems of resistance (as cited in Hijjawi, Ed.\& Trans. 2009). These representative poems are pregnant with feelings of defiance, indignation, and a need for defending and reserving their national identity against attempts of cultural appropriation. One of the most popular lyrics is spoken by a Palestinian rebel addressing Night before his scheduled execution at dawn: O Night, stay a little longer until the captive finishes his song. At dawn his wing will flutter, and the victim will swing in the wind, leaving his fledglings hungry at home and a widow who offered her only bracelet to rebels when her country cried for arms (Hijjawi, 2009, p.5). Such lines reveal utter defiance and readiness to sacrifice soul and gold to win homeland back. Other sensual verses as such are quite popular in Palestine, memorized and recited by most people, young and old. Among those are Mahmood Abdul-Raheem's two lines: I will carry my soul in my palm, and fling it in the road of doom/ Either a life pleasing the friend/ or a death agonizing the foe. Nothing is left for Palestinians but freedom or honorable death, as the poet states. Defiance of enemy is also strongly felt in Tawfiq Zayyad' popular poem The Impossible (as cited in Hijjawi, 2009, p.9). Zayyad defies that it could be easier for the oppressor to perform all the impossible tasks, but he cannot

Arab World English Journal for Translation \& Literary Studies 
destroy the shimmering glow of a belief/, a march, or our cause one single step. As Zayyad emphasizes, attachment to homeland is deeply rooted and cannot be erased.

Fadwa Tuqan's poem To Christ on his Birthday, (as cited in Hijjawi, 2009, p.18) speaks about the particular experience of her nation and sounds defiant and hopeful despite the ongoing destruction: out of deep sorrows/out of the freshness of our spilled blood/ out of the quivering of life and death/life will be reborn in you again. In her poem, Tuqan lays deep sorrow before Christ for all the joys of Jerusalem are crucified/ all the bells are silent/ the domes...in mourning/ ... Jerusalem is whipped/ under the cross/bleeding/ at the hands of the executioner. Salem Jubran, another displaced poet, wails his forced desertion of his hometown Safad in his poem The Exile (as cited in Hijjawi, 2009, pp. 12-13): Between your sky and my eyes/ A stretch of border walls/ blackens my view! In another poem named after his hometown Safad, Salem Jubran expresses nostalgic sentiments to Safad, where he is now merely an unwelcomed stranger among the current dwellers of erected houses: A funeral of mourning sits on my lips/and in my eyes/there sits a lion's humiliation/ Farewell/ farewell Safad. Sameeh Al Qassim, another prominent poet, often expresses sensual consciousness too as evident in the following verses (as cited in Samih AlQassim Poems). In his poem A Letter of a Bankrupt, he defies his enemy and vows revenge for robbing his land, ditching young fellows in prison holes. Despite the nightmare of terror imposed on his village, he defies, I shall not compromise/ And to the end/ I shall fight. At the same rate, AlQassim in The Wall Clock expresses utter dejection as he sees everything being collapsed, his neighborhood, the street, the square, home, and the wall. Time goes on and nothing has changed. In his poem, The Ashes, the same feelings of utter dejection engulf his tormented soul: love is now only words... no more yearning, no urgency, no real joy in our hearts/ no wonder in our eyes. Utter dejection also overflows his Confession in the Midday Sun, Out of agony, he turned the trunk of his planted tree into firewood, though spares some to make a flute, yet even the flute doesn't lift his dejected soul; he thus broke the flute, and lost the fruit and the tune, and mourned the tree. In his poem The Bats, the dream of freedom and struggle to win back his homeland never die, though suffocated by the watchful eyes of oppressor's police who trail him everywhere, to watch his pauses and moves. Still, he strongly believes that bats are on the verge of suicide, and he keeps digging a road to daylight. In Travel Tickets, his tone mellows somewhat showing feeble hope in the conscience of his killer and in the world body of justice. Before he dies, he would leave three travel tickets in his pocket, one to peace, one to the field and rain, and one to the conscience of humankind, and begs his killer to take them, use them, and ... travel (as cited in Samih AlQassim Poems).

In the aforementioned verses, the particular extends over the universal. In philosophical terms, the majority of poets have not gained yet the capability of transcending what the sensual consciousness dictates. Most react sensually due to the distressing circumstances, the continuity of world neglect, and above all the brutish consciousness of oppressor. Such bitter realities left no 
room for distressed souls to transcend the sensual consciousness, and thus remain resisting within the confines of the particular. Their poetry can be described as merely a particular protest against a particular injustice, battered spirits against a well-armed hostile executioner. Darwish in his wellknown poem A Lover From Palestine describes Palestinian struggle by the metaphor of the grass and rock: a more aggressive and hostile oppressor like the rock, against a more willful yet powerless oppressed people like the grass that defies the solidness of the concrete and keeps growing: Like grass growing among the joints of a rock/We existed as strangers one day (as cited in Joudah, 2007). No poet seems able to transcend the confines of sensual consciousness and treat bitter realities differently, and the reason is not hard to discern. Only people, one might say, endowed with heavenly stamina can transcend the particular with its unendurable pain and aspire to attain a divine stature.

\section{Mahmood Darwish}

In comparison to fellow poets, Darwish grows more universal in his vision especially in the final phases of his poetic career. In his final phases, Darwish strives to transcend the particular and embrace a cosmic vision. In his early verses, the sensual consciousness is dominant, though broader human touches can be felt even in his poetry of resistance. Human touches can be dated back to his early days at school. In a poem he wrote once to a Jewish classmate, he innocently wonders, why his fellow student has a house, yet he doesn't; why he and the Jewish boy are not allowed to play together. Decades later, Darwish recalls being summoned to see the military governor, who threatened him: "If you go on writing such poetry, I'll stop your father working in the quarry (Clark, 2008). As a young man, he joined the Israeli Communist Party (ICP), a party whom he thought it might be a key to counter with its nonsectarian ideology the Jewish Zionist sectarian ideology. Afterwards, he joined the new Arab party, Jabhat Al Ard (The Land Front), which evolved from the Israeli Communist Party (Jaggi, 2002). In additions, what deepened further his nonsectarian feelings in his early age was a notable love affair with a Jewish young lady (Ferber, 2014). Later, his consciousness grew broader as he mingled with international folks of different background and faith. After he left Palestine in 1971, Darwish closely communicated and integrated then with French, English, Latinos, beside Arabs and Jews. It could be that his intimate communication and integration with people of different walks and cultures inspired him with a new vision of the world, and stood behind the trends of non-exclusive love and peaceful coexistence inhabited his late poetry.

In the early phase of Darwish's poetry, the sensual consciousness is more dominant. His emotional reaction is expected of a young man whose land is confiscated and banished out of ancestral homeland; his house and entire village, al-Birwa, had been razed by the Israeli army and built upon a new settlement for strangers (Mattar, 2005; Taha, 2002). His popular poem Identity Card, as many of his early poems, recounts a desperate cry of an oppressed spirit in the face of oppressor. After establishing his own identity as a native to the land, he vows to avenge indignation and denial of identity: Write down, I am an Arab...I do not supplicate charity at your doors/ Nor I belittle myself at the footsteps of your chamber. In his outrage, he expresses pride in ancestral heritage and bluntly warns his oppressor of imminent consequences: You have stolen the orchard of my ancestors/ And the land I cultivated/... And you left nothing for us. For such atrocities, he 
boldly lays out an emotional warning: Write down... I do not hate people/ Nor do I encroach/But if I become hungry/ The Usurper's flesh will be my food/ Beware... of my hunger/ And my anger! (Joudah, Trans., 2007) In Defiance, Darwish registers another bold protest against a series of imprisonment and house arrest. He vows defiance no matter the place or the pain he endures: $I$ will say it/ In the detention room/ In the bathroom / In the barn / Under the whip/ Under the handcuff/ In the violence of chains/ A million birds on my heart branches /Make the fighting tune. Beside Identity Card and Defiance, many poems roam within the confines of sensual consciousness, even the poem dedicated to his Jewish sweetheart, Between Rita and my Eyes, a Rifle. The images encountered, however, are suggestive of a broad heart open to encompass others, mindless of culture or background. The divinity in those honey-colored eyes/, the moments of utter love, the loveliest of braids are all indicators of genuine feelings to a Jewish beloved. Yet his dream is frustrated by the prejudice of the rifle possessor. Their love, flowing as a stream and flying freely as a million sparrows, was Fired at by a rifle.

In the second phase of his career, Darwish continues reacting emotionally to the atrocities of a brutish enemy, yet a more mature tone is notably taking over. His tone seems more disputatious, and less threatening or blustering, as if the sensual consciousness, persistent before, has taken a new form. Still the particular is the leading drive. In O, You Who Pass Among Fleeting Words, (as cited in Joudah, 2007), Darwish beseeches peacefully the usurper to Be gone out of homeland after the latter snatches the blueness of the sky and the sand of memory. The usurper, in fact, is alien and has no connection to a land of peaceful agrarians equipped with nothing but stones, bare flesh and rain confronting a stranger armed to the teeth with steel and fire, tanks and gas bombs. He describes the conflict as a clash of existential proportion between a force of nature and a force of anti-nature: the rain, the motherland, the sky, and the sea verses a factitious entity made up of fleeting words, gas bombs, tanks and usurpation. As he says, from you the steel and the fire and from us our flesh. From you another tank and from us a stone/ From you another gas bomb and from us the rain. Nevertheless, he amicably asks the usurper to take your fill of our blood, be gone and enjoy your victory upon helpless people elsewhere, and leave us guarding the blossoms of martyrs or the grave grass at our overfilled graveyards. Such a peaceful call is given a deaf ear by the usurper, though the latter's claim to existence in Palestine is fraudulent and fictitious; it has no moral content whatsoever, but an unverified religious fancies, that ought to be piled in a deserted hole and be gone, ... the skeleton of your bird, ... and the holy calf. As the poem advances, the particular concern soon drifts into a broader image of mankind as a whole. A call for peace is insinuated as the poet resents witnessing the creatures of God on both sides who breathe the same air and live under the same sky engaging into a bloody campaign. By large, this poem in specific disappointed some of his Jew leftist friends who mistakenly interpreted his import as a call for the destruction of their state, an accusation Darwish played down and pressed his faith in peaceful coexistence with the other (Hadid, 2008).

In his poem On a Canaanite Rock at the Dead Sea, the tone is also disputatious, and less threatening or blustering, in addition the oeuvre of some lines renders universal relevance. He reminds once again that the usurper's claims to connection with his motherland is fictitious, fraudulent and lacking in moral or factual basis. In his argument, he surveys the history of Palestine 
and its inhabitants throughout the epochs of time. Palestine used to be a place of all monotheistic religions, and all people living in the green plains were Canaanites, closely connected to the salt of sea, birds, sky, and plains where Jericho [still] sleeps under her ancient tree, like baby Jesus Christ, yet with no one to rock her cradle. The religious controversy is reshuffled as he maintains, All the prophets are my family/ Yet heaven is still far from its land, and no divine intervention came along to redress man's wrong doing. The prophets have deserted his homeland, leaving behind fictitious and fraudulent testaments that incite bloody conflicts between followers. Since then, no white flags, is lifted to exchange declaration of peace. Despite history and its long controversies, his consciousness expands to contain both the natives and immigrants. Unlike his previous call for the stranger to Be gone, he extends his hand for peaceful co-existence:

Stranger, hang your weapons

Above our palm tree, so I may plant my wheat

in the sacred soil of Canaan,

Take wine from my jar. Take a page from my Gods' book.

Take a portion of my meal and gazelle from the traps of our shepherd's song...

Lay a single brick and build up a tower for doves, to be one of us

... be a neighbor to our wheat... leave Jericho under her palm tree

But do not steal my dream. (as cited in Jaudah, 2007)

He urges his opponent to realize the familiarity bond between the two nations, and coexist. Ironically, his genuine call is frustrated by the brutish consciousness of opponent, that seems unwilling to admit any human bond and unwilling to discard the past religious fancies and erase the old steam, leaving Darwish wavering between the dictates of the sensual and the trends of cosmic consciousness. Though dismayed, his trends of peaceful co-existence never wane. He repeatedly reminds his opponents: All the prophets are my family, to reassure the mystical unison of all people in Palestine and the cosmic idea that everybody is an essential part of the whole web regardless of various faiths. In practice, the followers of each faith reshape and mold heavenly revelations, and use religion as a motivation for conflict instead.

In Jerusalem, Darwish re-thrusts the idea of mystic unison of the three monotheistic religions' followers. To convey a sense of spiritual oneness, he uses references and language from Christianity, Islam and Judaism, treating the ancient traditions embodied in the city with almost impeccable equity (Horesh 2015). All religions are given their fair share of attention as though reiterating once again All the prophets are my family. The Christian Evangel, the Jewish Prophet Isaiah, Prophet Muhammad, the messenger of Islam, are all mentioned briefly: Words sprout like grass from Isaiah's messenger mouth: If you don't believe you won't be safe. As well, he introduces himself as another crucified Christ: And my wound a white biblical rose/ And my hands like two doves on the cross/ hovering and carrying the earth. Prophet Muhammad is also present in Jerusalem: But I think to myself: Alone, Prophet Muhammad spoke classical Arabic. The dream of spiritual unison, or cosmic vision, is soon shattered by bitter realities. Amidst his dream, $A$ 
woman soldier shouted: Is that you again? / Didn't I kill you? / I said: You killed me ... and I forgot, like you, to die. The same rifle, that ruins his dream to cross the barriers of hate with his Jewish beloved Rita, ruins once again his dream of spiritual oneness in Jerusalem. The dreamer is soon brought back to reality with the shout of a soldier at the end of the piece. In other words, his cosmic consciousness that renders non-exclusive love and mutual respect is frustrated by the incivility, hostility animosity, and intolerance of his brutish opponent.

During the last period of his career, Darwish searched for analogies or illuminating parallels with the Palestinian experience in the chronological records of losers: The Moors of Andalusia, the Natives Americans, the pagan cultures of the ancient Near East. Darwish used these chronicles of loss to amplify his sense of Palestinians' predicament (Creswell 2009). It could be said that his consciousness grew more cosmic, and the particular cause of his nation became part of a long struggle of the oppressed. In his poem The Last Speech of the Red Indian Chief, translated also by Joudah (2007), Darwish puts on an Indian garb to relate both the Palestinians' afflictions in the guise of Native Americans' afflictions. Despair, frustration, and a sense of loss are all manifested in this relatively long poem. Still a cosmic vision, that renders reconciliatory tone, cannot be missed in his verses. The Chief expresses first a strong faith in the divine spirit that animates their life, their pastures; as well as the grass that possesses a soul in us that could shelter the soul of earth. Their spirituality is further manifested as the Chief entreats his enemy, Don't kill the grass anymore/; sister tree has a spirit too and being tortured the way they 've tortured me. Yet the idea of spirituality falls way beyond the understanding of his opponents. Columbus, the emblem of brutishness, can't recognize the spirits roaming free between the sky and trees; thus he mocks their beliefs and calls their ghosts names of his liking, denying that all men are born equal. And worse, Columbus is bent on carrying out his deadly war, even after he took his fill from the flesh of our living and our dead. Despite Columbus' brutish consciousness, the Chief extends another hand for peace insomuch as does the persona in On a Canaanite Rock reminding Columbus Isn't about time, stranger, for us to meet ...., and share the sky, the air, and water; let us share the light, and take your fill of the night, but leave us a few stars to bury our celestial dead. The trends for peace are further pressed as the Chief reminds Columbus of freedom of faith: You have your god and we have ours. You have religion and we have ours. In contrast, Columbus has no real faith, only using God as a courtier in the palace of the king, and unwilling to tame the horses of madness, or to keep his wicked will in check. The brutish consciousness of Columbus, as opposed to the mystical consciousness of the Chief, is brilliantly hatched further in the Chief's emotional appeal: But if you must kill, white man, don't slay the creatures that befriended us. A deer will never approach grass that's been stained with our blood. To the Chief, the universe is entirely spiritual and entirely 
alive, and abound by the element of love, whereas to the invader it is only a game of gain, and a place of ruthless competition. In fact, Columbus and followers do not spare even the buffalos, the main life stock of the Natives: Buffalos are our brothers and sisters, as well as everything that grows, the turtle, the trees, the orchards, the blooms, and the river. Such heart-felt words do not appeal to the narrow consciousness of Columbus who arrogantly boasts,

We are the masters of time

Come to inherit the land of yours.

We want God all to ourselves

Because the best Indians are the dead Indians in the eyes of our Lord.

The Lord is white and the sky is white.

The process of destruction never ceases. It continues with the English guns, and sword, French wine and influenza; and Columbus establishes his kingdom in the hallow of a wounded space. Once again the trends for cosmic consciousness are stifled by the dictates of brutishness of the invader. In reaction, the Chief remains defiant, unwilling to sell a bit span of wheat farm and sign a peace treaty with the killers of his nation and nature. He would rather go back to his mother nature and leave his oppressor build his statue of fake liberty above his corpse. Death would bring no fright to the Indian Chief for it is only a unification with nature and resurrection of his immortal soul: We'll emerge from the flower of the grave. We'll lean out of the poplar's leaves/ of all that besieges you.

In brief, Darwish, like the Indian Chief, strives to abide by the dictates of cosmic or mystical consciousness, especially in the last phase of his poetic career, yet his inclinations are always suffocated by the brutish consciousness of his opponents. Though fully convinced that the Israelis' claims to connection with the land are fictitious, and lacking in moral or factual basis; however, he is willing to put the past behind, and keeps dreaming of a peaceful coexistence based on tolerance and mutual respect.

\section{Native Americans' Vision and Cosmic Consciousness}

Basically Native Americans' vision and culture bear resemblance to Bucke's cosmic consciousness, or Walt Whitman's vision. Like Whitman, they strongly believe in the immortality of the soul as their well-known sayings and doctrines reveal. They hold after a man dies, his spirit is somewhere on earth or in the sky,... we are sure that his spirit still lives... so it is with Wakantanka (Indian God)... he is everywhere, yet he is to us as the spirits of our friends, whose voices we cannot hear (American Indians Poems and Quotes). They also believe in the spiritual unison of the world as it is evident in Chief Seattle's words: all things share the same breath- the beast, the tree/ the man; the air shares its spirit with all the life it supports. The mystical oneness of the world appears also in some Indian doctrines: Humankind has not woven the web of life. We are but one thread within it.... All things are bound together. All things connect. To the Indians the universe is orderly designed: everything on the earth has a purpose, every disease an herb to 
cure it, and every person a mission (American Indians Poems and Quotes). Concurrently, they even feed their young children with ideas of the spirituality of the world and peaceful trends at schools as is the case in the Red Cloud Indian School. In a song, they beseech their Holy Spirit to give them strength not to be greater than my brother/, but to fight my greatest enemy-myself...so when life fades, my spirit may come to you without shame (American Indians Poems and Quotes). Other mystical ideas can be detected in Chief Crazy Horse's words: A very great vision (intuition) is needed and the man who has it must follow it as the eagle seeks the deepest blue of the sky. In additions, they believe in the goodness of man at the instant of birth. To them, the intimation of immortality is associated with children: Grown men can learn from very little children/ for the hearts of the little children are pure. Therefore, the Great Spirit may show to them/ many things which older people miss. Mutual respect and tolerance are also among the basic values of the Natives. Chief Tecumseh counsels: Trouble no more about their religion: respect others in their view and demand, they respect yours. In summary, one may feel inclined to suggest that the doctrines of Native Indians bear close resemblance to Whitman's cosmic consciousness.

\section{Sensual Poetry of the Natives}

Though the basic doctrines of Indians render to a great extent cosmic consciousness, bitter realities pushed most Indian poets to hover within the confines of the sensual or self-consciousness. The notable discrepancy, cited here, is not hard to discern. It could be said that the scar is too deep to put behind, or it could be said that the struggle of the living Indians have not come yet to a comforting conclusion, as is the struggle of Palestinians. Hence a great deal of Indian verses still recounts the past and present injustices and the atrocities they have endured for centuries. To many sensual poets, the infamous Wounded Knee Massacre of 1890 has ever since become an emblem of despicable cruelty, and a weeping wall for the Indian poets (Parsons, R. 2011). The phrase Bury My Heart at Wounded Knee is used poetically to encapsulate a broader sense of loss, grief, and outrage over the historic mistreatment and the continuing abuse of the Natives by government and big corporations. In paging the Indian Foundation of Poetry, one may encounter numerous examples of verses that fall within the confines of Sensual Consciousness. For instance, Colin Ian Jeffery recalls with sorrow the past bluffing of white soldiers who indiscriminately slaughtered young and old men, women, children, and even livestock, and left a few survivors to bury the victims at Wounded Knee Creek:

\section{Parents of Crazy Horse came to the fort \\ Took the body of warrior \\ Secretly burying majestic heart \\ At a place called Wounded Knee Creek}

Rebecca Miles, another Indian poet, blends the grave events of the Massacre with the on-going atrocities: Bury me at Wounded kneel for we won't do as we're told/ The women die from lack of food/ and our children are sold, all sold. Jude Kyrie follows suit in her irony of the bloody campaign against Indians: History of settlement marked in blood/... in all the time the land defiled/ with spilled blood of Indian child. Despite such despicable atrocities, in Washington the politicians sleep/ but I 
know why the willow tree weep. In the same manner, Smilling Stocks is also ironic of biased politicians, now and then. In his poem Bury my Heart at Wounded Knee, Stocks blends two scenes, one from the present where a Sioux Indian is taken to death chamber and a nurse, in charge of the cyanide hole... keeps the cards that read "Have Mercy on His Soul". This current scene recalls the infamous Massacre at wounded knee, and a linkage is brought home via the names of past and present politicians, Mr. Abraham Lincoln, Adolf Nixon, George Bush, Mr. $7^{\text {th }}$ Cavalry Jones. All politicians raised no eyebrow for the killing of innocent people, and worse they commissioned the killing meanwhile ask God to "Have Mercy" on their souls. In 1990, the same old phrase surfaced too in Buffy Sainte-Marie's song titled Bury my Heart at Wounded Knee, one of the greatest protest songs ever written. It is meant to draw the attention of world body of justice to the continuing abuse of the Natives' natural rights by government and big corporations. Esther Belin in Blues-ing focuses on the particular trauma of relocation that left Indian feeling lost and out of existence: And Coyote blues-ing on the urban brown funk vibe/ wanders in and out of existencel tasting the brown rusty at times/worn out bitter from relocation.

Despite the on-going atrocities, still most Native poets embrace peaceful means to redress the evil deeds. Joseph Ward-Langman, unexpectedly asks his fellow Indians, Do not kill, but do not yield; Bury my heart at the sacred land. Even in the famous Indians' protest in March 1972, the past carnage was present too. In his Black Hills, Ted Glick registers love to nature of snow-drops, honeyed-rain/ fall from the glistening green needles of upper reaches over Rapid City. In contrast, the sacred lands commercialized, organized/ centralized/scandalized by the white man. Tanya Winder speaks also about the particular humiliation of Indians: 1 in 3 Native women will be raped in her lifetime/ ... Native women are 2.5 times more likely to be sexually assaulted ... while the rest of the world keeps on eating. Winder surveys other forms of indignation: stealing our spirits each day... taking us away...to industrial schools to forced assimilation... genocide. The current atrocities, she demonstrates, are only a continuation of what had happened before, our bodies are targets marked for violence. ...our mothers swallowed these bullets long ago. Being extremely frightened, for Colonization's bullets sits cocked, waiting behind a finger on trigger. Despite the imminent danger, her nation is still alive and breathing. Like Tanya Winder, Mark Turcotte in his poem, Flies Buzzing, displays the Indians' love for life regardless of the pain and injustices around. His people keep dancing in the greasy light of kerosene lamps and recalling the inspiring spirits of ancestors, and singing, we shall live again. Sara Littlecrow- Russell in her Ghost Dance holds on to the same faith no matter the pain. Unlike what history books say... The ghost dance died with the ancestor..., she challenges, Each time it rains / I go to the sidewalk/ where the trees roots/ have broken the concrete/listening to the water's whispering: "It is coming soon." In fact, the ghost dancers were murdered dreaming of freedom and unison with the holy spirit, but the survivors still embrace the same old dream. They believe their nation will rise again like trees roots that break the concrete to preserve and restore the Native American's land and way of life.

Sherman Alexie, like others, engages mostly the particular rather than the universal. He illuminates despair, poverty, alcoholism, and other forms of self-abuse that often shape the life of Native Americans living on reservations. In his poem Grief Calls Us to the Things of This World, the persona feels fooled not only by white men but also by the angels who burden and 
unbalance us/... Those angels, forever falling, snare us/ And haul us, prey and praying, into dust. In his poem, How to Write the Great American Indian Novel, Alexie resents the particular hyphenation and stereotyping of his own nation, as well the racial pressure imposed even on their arts. An Indian novel cannot see the light, unless it suits the racial expectations of Anglo audience. All Indians characters must have tragic features: tragic noses, eyes, and arms. Racial specifications must be strictly observed too in the portrayals of Indian heroes and heroines. The hero must be a half-breed, half white and half Indian. The Indian heroine must be beautiful, slender/ and in love with a white man, or a half-breed Indian man. All Indian men, should be depicted as storms, and destroyer of the lives of any white women who choose to love them. As well, the Indian community ought to be inhabited by murderers, hopeless men, rapists and alcoholics.

Alexie's attachment to heritage and fear over cultural appropriation are illuminated in his poem My mother was a dictionary. His mother was a reservoir of Indian traditions, culture and language. With her death, the Indian heritage was entombed, or at best stored in a deteriorated cassette tape, a dictionary, a thesaurus, or an encyclopedia. The Powwow at the End of the World, is another typical Indian poem in which the particular prevails at the expense of the universal, hence signifying sensual consciousness. The poem speaks about a powwow, $a$ conference of North American Indians; a ceremony characterized by feasting, dancing, and rites performed (Ellis. 2003). The ceremony is meant to preserve and restore the Native American land and way of life. It may refer also to the past Ghost or Prophet Dance, a religious ceremony of resurrection of the dead, forbidden by the government in the nineteenth century, and participants often crushed by American troops (Brown, Dee. 2007). Apparently, the battered persona shows how unlikely he will forgive the ones who ruined their life and enslaved nature with man-made dams. He will forgive only when all wrongs put right again, after the first drop of floodwater is swallowed by that salmon waiting in the Pacific. In a Spokane myth, the salmon, the immortal agent of the holy spirit, was blocked from its own original stream by the dam. Given the idea that the salmon took human form in the ocean but transformed themselves into fish to be eaten. Neither forgiveness nor reconciliation would come till they have gathered around the fire with that salmon. Basically, once their tradition returns, forgiveness might be attained. At the end of the poem, he imaginatively topples the man-made dam and unleashes the waters, anticipating that human arrogance would inevitably come to an end, and the salmon would finally swim upstream past the flooded cities, broken dams and abandoned reactors of Hanford. By large, the poem illuminates the Indian's trauma; yet as other cited verses, it falls within the confines of Sensual Consciousness.

Compared to the particularity extant in the aforementioned poems, Alexie's Hymn entangles more universal issues. In other words, it transcends the confines of the particular and encompasses a non-exclusive vision. In more specific terms, the sensual level dominant before has given way to a rather cosmic vision in which the particular plight of Indians becomes part of the universal struggle. Alexie surveys the evolution of human mind from the lowest brutish selfawareness, to the sensual consciousness, and then to a higher self-consciousness, as though tracing the forms of consciousness illuminated by both Bucke and Schleiermacher. The begins with the 
brutish self-awareness in which men act like beasts, love their progeny, as any lion can be devoted to its cubs, as well Any insect, be it prey/ Or predator, worships its own DNA. This kind of love draws mockery not admiration: It ain't that hard/To love somebody who resembles you... with the same chin/ And skin and religion and accent and eyes. This form of love suits a caveman who is closer to brutes in his sentiments and afraid of the things outside the cave. Incivility, volcanic hostility, lists of enemies, and moral apocalypse - are all features of brutes not real humans. In Schleiermacher's theology, a man remains brutish in consciousness unless he transcends animal instincts and attain a point of contact with the absolute, with no doubt entails non-exclusive love (Bunge 2001). The brutish awareness is mocked further as the fans worship beneath the tarnished steeple and admire the lack of compassion of their abhorrent dictator. And worse, they are convinced that their deadly sins (Envy, wrath, greed) have transformed into wins, misusing religious fiction to justify aversions against others of different race, religion or culture. To make amends, the divisive brutish consciousness is to be encountered by a new vision of non-exclusive love: I know I will still feel my rage and rage I But I won't act like I'm the only person on stage... I will resist hate... I will stand and sing my love... and sing to welcome strangers; as though The Powwow dictated by Alexie's sensual consciousness has evolved into a cosmic one that encompasses people of different walks. In other words, Alexie transcends the particular in this specific poem and realizes the idea of non-exclusive love as the essence of creation; as well he deems everyone part of the human fabric; and everyone shares in the truly essential things in life.

\section{Joy Harjo}

Among the rest of the Native American poets, Joy Harjo often shows serious inclinations to transcend the particular and adopt a rather Whitmanian cosmic vision, cemented by Creek values, myths, and beliefs. Harjo chants a unity of the whole universe and a mystical unison among humans, animals, plants, the sky, and earth. In additions, she believes that we become most human when we understand the connection among all living things (Romero, 2012). She also embraces the spirituality of world, the idea of non-exclusive love and the beauty of the whole web. However, like Darwish, her inclinations are often frustrated by distressing realities- the brutish consciousness of her opponents. Harjo grew up in slums and shacks of poor Indians in Tulsa, Oklahoma, a background that deeply informs her work. As growing up, Harjo learned how to maintain and integrate with others without losing or denying her own identity. Like Darwish, she has nurtured herself to adopt and display a cosmic consciousness of her own liking, perhaps for the purpose of containing the reminiscence of past injuries. To some degree, the particular in her verses often surrenders its place to a more universal vision. As she comments once, the concerns are particular, yet often universal (Poetry Foundation/ Joy Harjo). Following the footsteps of Walt Whitman, her incantations excludes nothing; it inhabits all American landscapes and revolves around the need for remembrance in order not to deny or lose her own identity, and transcendence in order to rise above the atrocities of brutish consciousness of opponents. In a published interview, she states that she feels strongly obliged to all past and future ancestors, to home country, to all places... to all voices, all women, all of [her] tribe, all people, all earth, and beyond that to all beginnings and 
endings (Poetry Foundation/ Joy Harjo). She often touches upon land rights for Native Americans, meanwhile she strives to bring realization of the wrongs of the past, not only for Native American communities but also for oppressed communities worldwide (Valenzuela-Mendoza, 2014).

In her poem the Eagle, (as cited in Poetry Foundation) the Indian heritage and Whitman's vision of higher consciousness inform her verses. Like Whitman, she celebrates not only herself, but all humanity, and indicates that spiritual moments can lead to peace, joy, and knowledge. While praying, her soul transcends the particular and unfolds to encompass the whole world.: To pray you open your whole self/ To sky, to earth, to sun, to moon/To one whole voice that is you/ And know there is more. Genuine prayer, as she states, would sweep our hearts clean. And in moments of mystical illumination, we learn That we must take the utmost care/ And kindness in all things, for every creature is part of the same fabric, and shares in the truly essential things in life. As well, birth and death are part of life journey, yet all should be done in beauty, without hyphenation or segregation. The same vision of spiritual oneness and non-exclusive love, she reiterates in her poem This Morning I Pray for My Enemy. To her, a human heart should be a conduit through which all man's thoughts and moves should pass: the door to the mind should only open from the heart. A human heart should be open and admit even the foe who dares to be a friend: An enemy who gets in, risks the danger of becoming a friend, as she concludes her poem.

In her Reconciliation- A Prayer, Harjo channels also Walt Whitman particularly in his wellknown poem Reconciliation, the concluding poem in Drum Taps, written as the American Civil War came to a close. Like Whitman, Harjo based her discourse on the spirituality of the world and the idea of non-exclusive love. Her lines showcase the divine spirit living at the root of molecular structure in all life as a dynamic force, all-pervading and all-loving; it reveals itself at all levels, humans, animals, plants, minerals, as well as in the essence of the sun (Robertson, 2010). Unlike Alexie's one color gathering in The Powwow at the End of the World, Harjo's powwow encompasses not only the Natives, but all God's creatures. She invites all people to take part in her prayer, embracing the idea that the foundation of all religious experiences is mystical illumination that all need (James, 1892; Moores 2006). In her poem, the mystical unison of the whole world is attained through a precise balance among the symbols of Christianity, and Indians' faith. The Indian symbols of love and spirituality merge with the Christian sacrament of the Last Supper: This god who grew to love us became our lover, sharing/ tables of food enough for everyone in this whole world. This traditional image of Christ accompanies the image of her Indian Gods: Oh sun, moon, stars, our other relatives peering at us/from the inside of god's house. Keep us from giving up in the land of nightmares and miracles. Despite differences in rituals, acts of kindness must be the lights for all decent worshipers. With no illusion of domination nor undertaking, people should move forward together tolerating the shape and faith of one another with compassion. She further prays that all the strands broken from the web of lifel shiver with love and sing for the welfare of the whole universe.

Arab World English Journal for Translation \& Literary Studies 
In Remember, also the particular gives its place to a universal vision in which all the factions in conflict should be abound in love. Like Whitman who chants always the oneness of the universe, Harjo encompasses in her broader image the whole universe, the sky, the sun, the moon, the sunrise, the sunset, the mother, the father, the earth. plants, trees, animals, as essential parts of the whole web of life. Nothing is excluded. All are abounding in love, she adds. Only with nonexclusive love, people of different faith, color, or gender can retain and embrace the oneness of the whole world.

In the Equinox, Harjo seems wavering between the dictates of the sensual consciousness and the mandate of a cosmic vision: either to keep fighting, or to extend her arm to meet others at the middle of the road. The sensual that tempts her to carry a war club as the grief staggering toward the sun is eventually kept in check. Instead, she resorts to a comforting idea of the eternal, for eternity encompasses the whole; and her addiction to war and desire have been broken. She consciously decides to have the dead buried and to make songs of the blood, the marrow. Reconciliatory tone is to prevail despite the spilled blood and racial grudge. However, cosmic consciousness, which renders love, is nearly shaken by bitter realities, and evaded by the aggressor's insistence on his bloody game. Her plan of transcendence is soon dodged by the reservoir of remembrance. An alarming thought from the past encroaches on her: How they would forget our friendship, would return to kill me and the babies. Her fear is temporarily overcome by inclinations to love the whole world while whirling joyfully on the dance floor. Still, even the joy she finds in dancing is frustrated and evaporated by the staccato of the bullets, and the artillery she sees in the hands of dictators.

With a slight difference, her poem An American Sunrise reiterates the same peaceful trends, meanwhile those trends are suppressed by the prejudice and the brutish consciousness of oppressors. While revisiting the land of ancestors with its reminiscent of pain and grief, she strives to keep the sensual in check: surfacing the edge of our ancestors' fights, and ready to strike. With alcohol and dancing, she tends to remember to forget the atrocities of others and rises above worldly pains: We drummed a fire-lit pathway up to those starry stars, and integrate and rather assimilate, yet the other is still in the habit of using religious fiction to stigmatize the Natives as heathens or anti-Christ: Sin was invented by the Christians, as was the Devil, we sang/. We were the heathens, and there is only a thin chance to be saved from them. Against all odds, justice has not been done for Native Indians yet: forty years later and we still want justice, she concludes.

In brief, Harjo's verses flicker between the sensual consciousness that entails remembrance of all the past indignation, massacres, and on-going injustices; and an earnest impulse to transcend the past with all its injuries and adopt a cosmic vision that sees the whole universe as one, abound by the idea of non-exclusive love and justice for all regardless of race, gender, or faith. Her cosmic inclinations, however, are often frustrated by the brutish consciousness of the other. Still, she believes that time has come for humanity to turn a new page, and she anticipates that the consciousness of all people will eventually develop into the highest form of human consciousness.

Arab World English Journal for Translation \& Literary Studies 


\section{Conclusion}

The majority of indigenous people's verses hover within the confines of the sensual consciousness. In contrast, Darwish and Harjo cherish a universal vision that considers all creatures on earth as one, and dream of a historic reconciliation based on justice for all, tolerance of the other, and above all the idea of non-exclusive love that encompasses foes and friends among the factions in conflict. In the examined verses of both poets, the particular goes side by side with the universal, or the sensual with the cosmic. Both expose the injustices befall their nations, and concurrently strive to transcend the particular and the mandates of the brutish consciousness and attain a point of contact with the absolute. This is not to argue that Darwish and Harjo adopt completely cosmic consciousness; they showcase earnest trends for such a vision, yet their inclinations are always frustrated by harsh realities- the brutish consciousness of their oppressors. Hope, though a feeble one, is still there, as Darwish once relates: I do not despair. I am patient

and waiting for a profound revolution in the consciousness of the Israelis.... All it has to do is to open the gates of its fortress and make peace (as cited in Hadid, 2008).

\section{About the Author:}

Dr. Adil M. Jamil, specialized in American Poetry with a Master's degree from Marshall University, USA, and a Doctoral Degree from MTSU, USA., is now a chairman of the Department of English at Amman Arab University, having growing interest in the life and Arts of Indigenous people, beside Creative Writing. ORCID ID https://orcid.org/0000-0001-59162782

\section{References}

American Indian Poems and Quotes. Retrieved from https://www.beccascorner.tripod.com/id22.html.

Bucke, M. (2009). Cosmic Consciousness: A Study in the Evolution of the Human Mind. Mineola, New York: Dover Publications.

Brown, D. (2007). Bury my heart at Wounded Knee: An Indian history of the American West. New York: Macmillan.

Bunge, M. J. (2000). The Child in Christian Thought. Grand Rapids, Michigan: Wm. B. Eerdmans Publishing

Clark, P. (2008, August 11). Mahmood Darwish. The Guardian. Retrieved from https://www.theguardian.com/books/2008/aug/11/poetry.israelandthepalestinians

Cook, A. L. (1950). "A Note on Whitman's Symbolism in 'Song of Myself". Modern Language Notes 65.4: 228-32. JSTOR. Web. 17 October 2011

Creswell, R. (February 2009). "Unbeliever in the Impossible: Poetry of Mahmoud Darwish". Harper's 318 (1905): 69-74

Darwish, M. (2007). The Butterfly's Burden. Trans by Fadi Joudah. Port. Townsend, Washington: Copper Canyon Press.

Ellis, C. (2003). A Dancing People: Powwow Culture on the Southern Plains.

Lawrence, Kansas: University Press of Kansas.

Arab World English Journal for Translation \& Literary Studies 
Ferber, A. (2014. June 4). When the Palestinian National Poet Fell in Love with a Jew: The Love Letters Between Mahmood Darwish and 'Rita'. HAARETZ. Retrieved from https://www.haaretz.com/jewish/.premium-palestinian-poet-in-love-with-a-jew1.5250557. April 18, 2019.

Hadid, D. (9. August, 2008). Palestinian Poet Mahmoud Darwish Dead at 67. Seattle Times. Retrieved from https://wikivisually.com/wiki/Mahmoud_Darwish

Hijjawi, S. Ed. \&Trans (2009). Poetry of Resistance in Occupied Palestine by Ghassan Kanafani. Baghdad: Ministry of Culture Press, 1968.

Horesh, U. (2015). In Jerusalem by Mahmoud Darwish. Transference: 3 (1) Huyssteen, W. V. (2003). Encyclopedia of Science and Religion, Volume 2. New York, Macmillan Press

Jaggi, M. (June 8, 2002) Profile: Mahmoud Darwish - Poet of the Arab world, The Guardian, Retrieved from https://www.theguardian.com/books/2002/jun/08/featuresreviews.guardianreview19

Mattar, P. ed. (2005). Encyclopedia of the Palestinians. New York, NY: Facts on File.

Moores, D.J. (2006). Mystical Discourse in Wordsworth and Whitman: A Transatlantic Bridge. Leuven, Belgium: Peters Publisher.

Nassar, H. K. \& Rahman. N. (eds.), (2007). Mahmoud Darwish, Exile's Poet: Critical Essays. Northampton, MA: Interlink Books,

Parini, J. (March 11, 2011). The 10 Best American Poems. The Guardian. Retrieved from https://www.theguardian.com/books/booksblog/2011/mar/11/best-american-poems.

Parsons, R. (2011). The Wounded Knee Massacre, December 1890. Retrieved from https//www.lastoftheindependents.com.

Poem Hunter, Samih Al-Qassim Poems, https:/www.poemhunter.com/samih-al-qasim/

Poetry Foundation, Poets. https://www.poetryfoundation.org/poets. All the verses of Native American are cited in this website.

Reynolds, D.( 1995.) Walt Whitman's America: A Cultural Biography. New York: Alfred A. Knopf,

Redding, P. (2011) Whitman Unbound: Democracy and Poetic Form. New Literary Theory 41.(3)(669-90.

Richardson, H. (2010). Wounded Knee: Party Politics and Road to An American Massacre. New York: Basic Books

Robertson, M. (2010) Worshipping Wall: The Whitman Disciples. Princeton University Press Romero, C. (2012). Activism and the American Novel: Religion and Resistance in Fiction by Women of Color. Virginia: University of Virginia Press.

Shatz, A. (2001, December 22). A Poet's Palestine as a Metaphor. The New York Times, Retrieved from https://www.nytimes.com/2001/12/22/books/a-poet-s-palestine-as-ametaphor.html

Taha, I. (2002). The Palestinian Novel: a communication study. London: Routledge.

Valenzuela-Mendoza, E. (2014). Tending to the past: The Historical Poetics of Joy Harjo and Natasha Trethewey". Iowa Research Online. 1 (7).

Whitman, Walt. (2016) Song of Myself. Iowa City: Iowa University Press. 